\title{
Adsorption of cobalt ions from waste water on activated Saudi clays
}

\author{
Saad A. Al-Jlil
}

Received: 7 July 2013/ Accepted: 29 October 2014/Published online: 18 November 2014

(c) The Author(s) 2014. This article is published with open access at Springerlink.com

\begin{abstract}
The aim of this work was to remove the Cobalt ions from wastewater by three types of Saudi clay. These were collected from Tabbuk city (Tabbuk clay), Khiber city (Khiber clay), and Bahhah city (Bahhah clay). The paper also examined the effect of different activators on the enhancement of adsorption capacity of clays for cobalt ions. The results showed minor enhancement in the adsorption capacities of cobalt ions on three types of clays activated by acid treatment. The adsorption capacity of clays improved particularly for Tabbuk clay when treated with hydrogen peroxide as an activator. The adsorption capacity increased from 3.94 to $12.9 \mathrm{mg} / \mathrm{g}$ for the untreated and treated Tabbuk clay, respectively. Also, the adsorption capacity of Bahhah clay increased by activating with sodium chloride from 3.44 to $12.55 \mathrm{mg} / \mathrm{g}$ for untreated and treated sample, respectively. The equilibrium adsorption data were correlated using five equilibrium equations, namely, Langmuir, Freundlich, Langmuir-Freundlich, BET, and Toth isotherm equations. Langmuir isotherm agreed well with the experimental data of Khiber and Bahhah clay, while Freundlich model and Langmuir-Freundlich model fitted well with the experimental data of Tabbuk and Bahhah clay activated by $\mathrm{NaCl}$. The results showed that Freundlich model fitted well with the experimental data of Tabbuk clay when activated by $\mathrm{H}_{2} \mathrm{O}_{2}$ and $\mathrm{H}_{2} \mathrm{SO}_{4}$. Finally, the BET model did not describe the experimental data well for the three types of clay after activation.
\end{abstract}

Keywords Saudi clays · Adsorption capacity · Enhancement - Different activators - Hydrogen peroxide · Equilibrium models

\section{List of symbols}

$M \quad$ Clay mass $(\mathrm{g})$

$v \quad$ Volume of the solution (1)

$q_{\mathrm{e}} \quad$ Amount of cobalt ions adsorption $(\mathrm{mg} / \mathrm{g})$

$C_{0} \quad$ Initial solution concentration of cobalt ions ( $\left.\mathrm{mg} / \mathrm{lit}\right)$

$C_{\mathrm{e}} \quad$ Concentration of the cobalt ions at equilibrium $(\mathrm{mg} / \mathrm{l})$

$K$ Equilibrium parameter of Langmuir model $(1 / \mathrm{g})$

$B$ Equilibrium parameter of Langmuir model $(1 / \mathrm{mg})$

$R \quad$ Dimensionless equilibrium parameter $(-)$

$K_{F} \quad$ Equilibrium parameter of Freundlich model $(1 / \mathrm{g})$

$n \quad$ Equilibrium parameter of Freundlich model (-)

$K_{\mathrm{c}} \quad$ Equilibrium parameter of Langmuir and Freundlich model (1/g)

$b_{c} \quad$ Equilibrium parameter of Langmuir and Freundlich model (1/mg)

$m$ Equilibrium parameter of Langmuir and Freundlich model (-)

$K_{t} \quad$ Equilibrium parameter of Toth model $(1 / \mathrm{g})$

$b_{t} \quad$ Equilibrium parameter of Toth model $(1 / \mathrm{mg})$

$t \quad$ Equilibrium parameter of Toth model (-)

$K_{\mathrm{B}} \quad$ Equilibrium parameter of BET model $(\mathrm{l} / \mathrm{g})$

$b_{\mathrm{B}} \quad$ Equilibrium parameter of BET model $(1 / \mathrm{mg})$
S. A. Al-Jlil ( $\square)$

National Center for Water Technology (NCWT), King

Abdulaziz City for Science and Technology (KACST),

P. O. Box 6086, Riyadh, Kingdom of Saudi Arabia

e-mail: saljlil@kacst.edu.sa

\section{Introduction}

Recently, in Saudi Arabia, wastewater was found to be contaminated with different types of heavy metals. Therefore, there is a need to concentrate on wastewater treatment 
to improve its quality for reuse in industrial and agriculture sectors in order to save fresh groundwater and minimize the cost of seawater desalination. The cobalt (Co) ion is considered to be one of the major toxic heavy metal pollutants in wastewater and its contamination is from electroplating, catalytic processes, ceramic, and alloys industries (Brezonik 1974; Patterson and Passino 1987; Emsley 1992).

Although wastewater treatment to remove cobalt ions can be achieved by different traditional processes such as membrane process, chemical precipitation, and ion exchange process, but another approach of wastewater treatment is separation by the adsorption processes.

Adsorption process is one of the tools in wastewater treatment. Because, it is a cost-effective solution for the separation of pollutants where it does not require energy for phase changes as in the distillation and it mainly depends on the type of adsorbent. Hence, the main advantage of adsorption process, in general, is the use of low cost adsorbent especially the natural clay.

Numerous investigators have tested different types of activators and activation techniques to enhance the adsorption capacities of several types of clay (Eren 2008; Dogan et al. 2008; Stathi et al. 2007; Unuabonah et al. 2007; Diaz et al. 2007; Adebowale et al. 2005; Al-Asheh et al. 2003; Singh et al. 2001; Suraj et al. 1998). But till date, no study has been carried on the activated Saudi clays to adsorb cobalt ions.

Adsorption of copper ions on bentonite/manganese oxide composite was investigated using batch adsorber by Eren (2008), who found an increase in the adsorption capacity of the composite clay in comparison with bentonite clay. The adsorption of heavy metals, such as cobalt and copper on modified surface of sepiolite clay was studied by Dogan et al. (2008), who modified the surface of this clay by trimethoxysilane and [3-(2-aminoethylamino) propyl]. Also by increasing the $\mathrm{pH}$, the adsorption capacity of clay was increased. Adsorption of lead, cadmium, and zinc on four organic-modified montmorillonite clays were investigated by Stathi et al. (2007). The adsorption capacity and selectivity of ions was better than the unmodified clay. Tripolyphosphate-impregnated Nigerian kaolinite clay was studied by changing the $\mathrm{pH}$ of the solution, whereby, the adsorption of lead ions depended on the $\mathrm{pH}$ of the solution. For example, at $\mathrm{pH}=4$ with $500 \mathrm{ppm}$ lead ions, the adsorption capacity was $24.7 \mathrm{mg} / \mathrm{g}$ (Unuabonah et al. 2007). Hectorite clay from USA and vermiculite clay from Spain were converted to functionalized hectorite and functionalized vermiculite using thiol groups and then used to adsorb lead ions from aqueous solution. The adsorption of lead ion from functionalized vermiculite clay was greater than functionalized hectorite, where the adsorption capacity was $33 \mathrm{mg} / \mathrm{g}$ for functionalized vermiculite and $10 \mathrm{mg} / \mathrm{g}$ for functionalized hectorite (Diaz et al. 2007).
Table 1 Chemical analysis of three types of natural clay by XRF (wt \%)

\begin{tabular}{lccc}
\hline Oxides & \multicolumn{3}{l}{ Type of natural clay } \\
\cline { 2 - 4 } & Khiber clay & Tabbuk clay & Bahhah clay \\
\hline $\mathrm{SiO}_{2}$ & 44.1554 & 41.1489 & 40.0106 \\
$\mathrm{Al}_{2} \mathrm{O}_{3}$ & 14.2844 & 14.3788 & 12.206 \\
$\mathrm{~K}_{2} \mathrm{O}$ & 0.7468 & - & 0.3011 \\
$\mathrm{CaO}$ & 8.4791 & 5.9885 & 9.5285 \\
$\mathrm{TiO}_{2}$ & 1.1843 & 0.4837 & 1.8515 \\
$\mathrm{MgO}$ & 8.390 & 9.8491 & 6.7485 \\
$\mathrm{MnO}$ & 0.1937 & 0.1420 & 0.2195 \\
$\mathrm{Fe}_{2} \mathrm{O}_{3}$ & 10.9089 & 10.0939 & 13.5396 \\
$\mathrm{Na}_{2} \mathrm{O}$ & 2.3455 & 1.7658 & 2.2511 \\
$\mathrm{P}_{2} \mathrm{O}_{5}$ & 0.3666 & - & 0.3208 \\
$\mathrm{Cr}_{2} \mathrm{O}_{3}$ & 0.1608 & - & - \\
$\mathrm{L} . \mathrm{O} . \mathrm{I}$. & 8.7845 & 16.14 & 13.02 \\
\hline $\mathrm{L} . \mathrm{O}$ & & &
\end{tabular}

L.O.I. Loss-On-Ignition

Adsorption of lead ions, cadmium ions, zinc ions, and copper ions by phosphate and sulfate modified kaolin clay from Nigeria was studied (Adebowale et al. 2005). The adsorption capacity increased for adsorption of these heavy metals. The methylene blue adsorption on activated bentonite clay was studied by Al-Asheh et al. (2003). The activation of bentonite clay by sodium dodecyl sulfate showed that the adsorption capacity was better than the natural bentonite. Adsorption of lead ions on phosphatic clay from USA was investigated using batch equilibrium technique. The adsorption capacity of lead was $32 \mathrm{mg} / \mathrm{g}$ (Singh et al. 2001). Adsorption of copper ions and cadmium ions on two modified kaolinites from Kerala was investigated (Suraj et al. 1998). The clay was modified by calcination and activated by acid. The adsorption capacity decreased by the increase in calcination temperature.

The aim of this study was to determine the improvement in the adsorption capacities of Tabbuk clay, Khiber clay, and Bahhah clay by different activators for cobalt ions from wastewater.

\section{Experimental}

\section{Materials}

Three types of Saudi natural clay were used as adsorbents. These were obtained from different locations. (1) The quartz as major and dolomite and calcite as minor (Khiber clay) was collected from Khiber city, north-west of Saudi Arabia. (2) The quartz as major and calcite as minor (Bahhah clay) was collected from Bahhah city, Asser region in the south of Saudi Arabia, and (3) the quartz as 

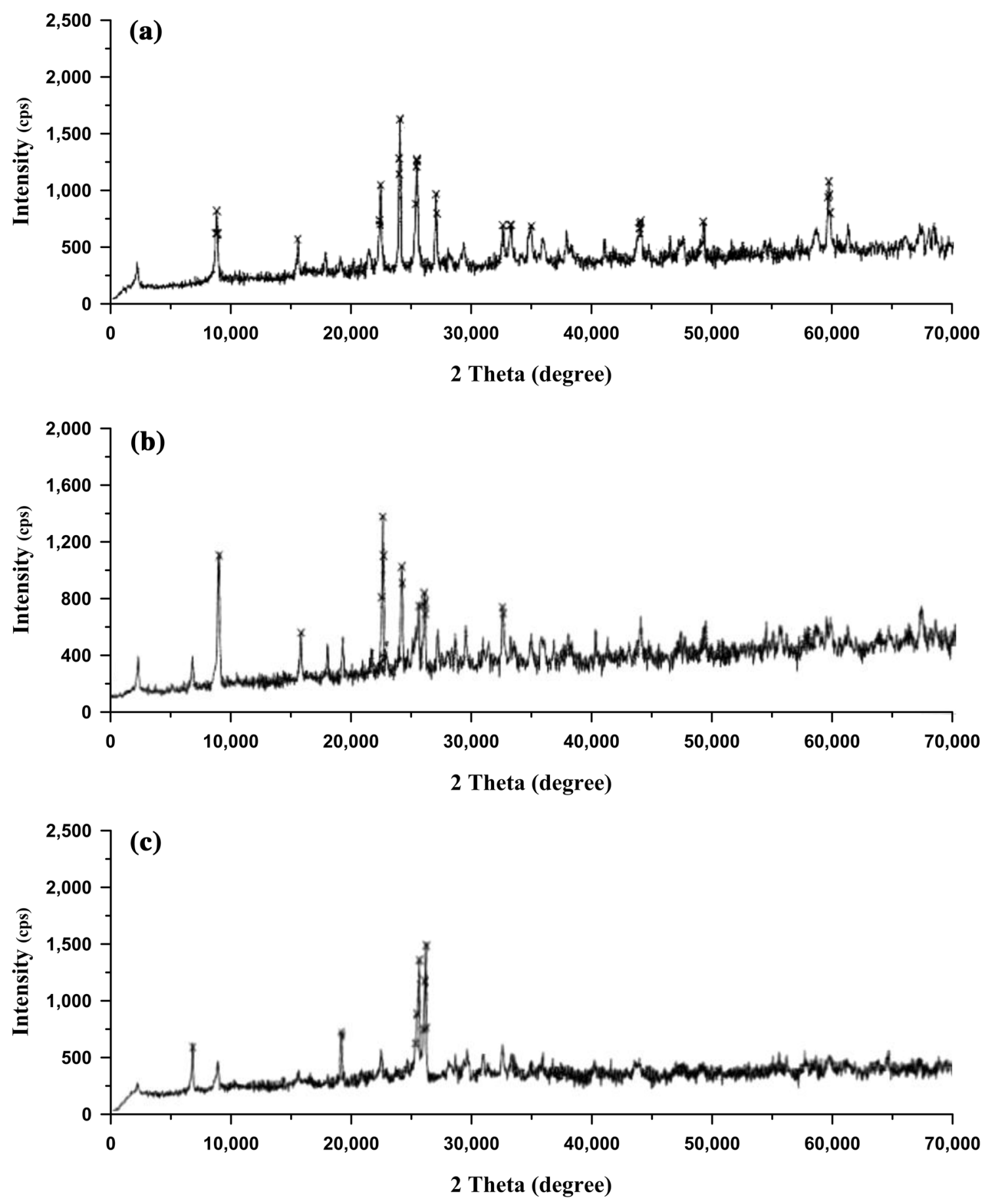

Fig. 1 a XRD for Tabbuk clay, b XRD for Bahhah clay, c XRD for Khiber clay

major and illite and chlorite as minor (Tabbuk clay) was collected from Tabbuk city, north of Saudi Arabia. The chemical analysis of the three types of Saudi natural clays was carried out by XRF (model JSX-3201, JEOL, Element Analyzer) (Table 1) and XRD (model D8AD VANCE, BRUKER) (Fig. 1a, b, c). The range of the XRD was 2-70 $\theta$.
The surface area and pore characteristics of the three types of Saudi natural clay were carried by surface area analyzer (model ASAP 2020, Micromeritics) (Table 2).

The adsorbate used was the cobalt ions solution prepared from cobalt (II) nitrate purified LR $\left[\mathrm{Co}\left(\mathrm{NO}_{3}\right)_{2}\right]$ and supplied by VWR International SAS 201, Rue Camot- F94126, Sous bois. 
Table 2 Surface area and pore characteristics of three types of saudi natural clay

\begin{tabular}{lccc}
\hline Element & \multicolumn{2}{l}{ Type of natural clays } \\
\cline { 2 - 4 } & Khiber clay $\begin{array}{l}\text { Tabbuk } \\
\text { clay }\end{array}$ & $\begin{array}{l}\text { Bahhah } \\
\text { clay }\end{array}$ \\
\hline BET surface area $\left(\mathrm{m}^{2} / \mathrm{g}\right)$ & 1.1175 & 1.4782 & 0.3799 \\
$\begin{array}{l}\text { Pore volume at }\left(p / p_{0}=0.97\right) \\
\left(\mathrm{cm}^{3} / \mathrm{g}\right)\end{array}$ & 0.004001 & 0.006078 & 0.001300 \\
$\begin{array}{l}\text { Average pore width }(\AA) \\
\text { Average pore diameter }(\AA)\end{array}$ & 143.2000 & 164.4571 & 136.8600 \\
\hline
\end{tabular}

Activation of the three types of clay

The three clays were activated by sulfuric acid $\left(\mathrm{H}_{2} \mathrm{SO}_{4}\right)$, hydrogen peroxide $\left(\mathrm{H}_{2} \mathrm{O}_{2}\right)$, and sodium chloride $(\mathrm{NaCl})$ at activation condition $\left(1 \mathrm{M}, 1 \mathrm{~h}, 25^{\circ} \mathrm{C}\right)$.

To activate the clays, $8.0 \mathrm{~g}$ samples were placed in flasks with $25 \mathrm{ml}$ of $1.0 \mathrm{M}$ activator solution and stirred under the above stated conditions. Then, the mixture was filtered and washed with distilled water for several times. The clay samples were air-dried for $24 \mathrm{~h}$ and used in equilibrium adsorption experiments.

\section{Equilibrium experiments}

Equilibrium isotherms were obtained, for the natural and activated clays (Tabbuk, Bahhah, and Khiber), by mixing a constant mass of clay $(1 \mathrm{~g})$ with $50 \mathrm{ml}$ cobalt ion solutions in glass bottles on a constant agitating shaker ( $250 \mathrm{rpm})$. In all isotherm runs, the concentration of cobalt ions in solution ranged from 50-2,000 ppm. The particle size of clay was $0.25 \mathrm{~mm}$ and the temperature of the experimental conditions was $25^{\circ} \mathrm{C}$.

The adsorption of cobalt ions and clay system reached to state of equilibrium after $40 \mathrm{~min}$ as shown in Fig. 2.

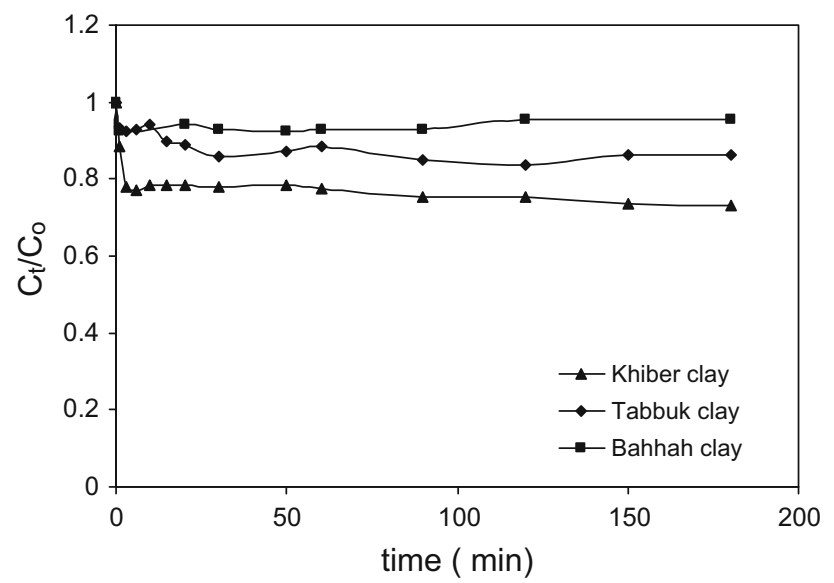

Fig. 2 Time equilibrium for adsorption of cobalt ions on different types of natural clay

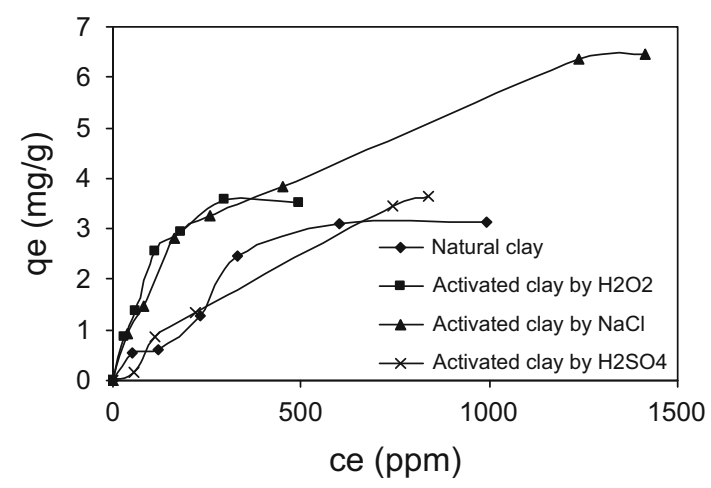

Fig. 3 Activation of Bahhah clay by different activators for adsorption of cobalt ions

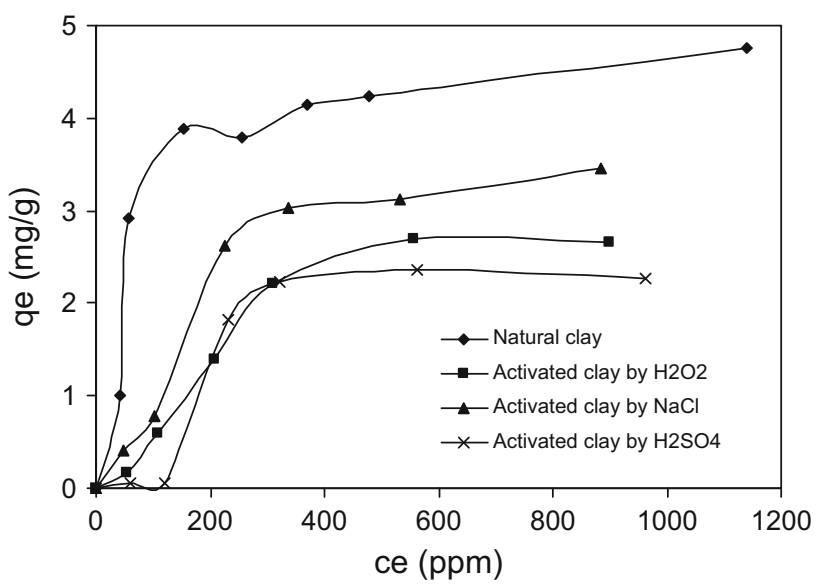

Fig. 4 Activation of Khiber clay by different activators for adsorption of cobalt ions

However, the equilibrium process was run for $3 \mathrm{~h}$ to ensure that the adsorption process has attained the state of equilibrium. After this process, the samples were filtered, then diluted and the absorbance was measured by atomic absorption spectroscopy. Later on, the absorbance of samples was converted to concentrations using the calibration curve for cobalt ions. The cobalt ions adsorption on the activated clay was obtained from the mass balance equation on the batch adsorber as follows:

$q_{\mathrm{e}}=\frac{V\left(C_{0}-C_{\mathrm{e}}\right)}{M}$,

where $M$ is mass of clay $(\mathrm{g}) . V$ is volume of the cobalt ions solution (1), $q_{\mathrm{e}}$ is the cobalt ions adsorption on the clay $(\mathrm{mg} / \mathrm{g}), C_{0}$ is initial concentration of cobalt ions $(\mathrm{mg} / \mathrm{l})$, and $C_{\mathrm{e}}$ is equilibrium concentration of the cobalt ions ( $\left.\mathrm{mg} / \mathrm{l}\right)$. The cobalt ions adsorption on natural and activated clays against the equilibrium concentration of the cobalt ions was plotted to obtain the equilibrium adsorption isotherm curves. 


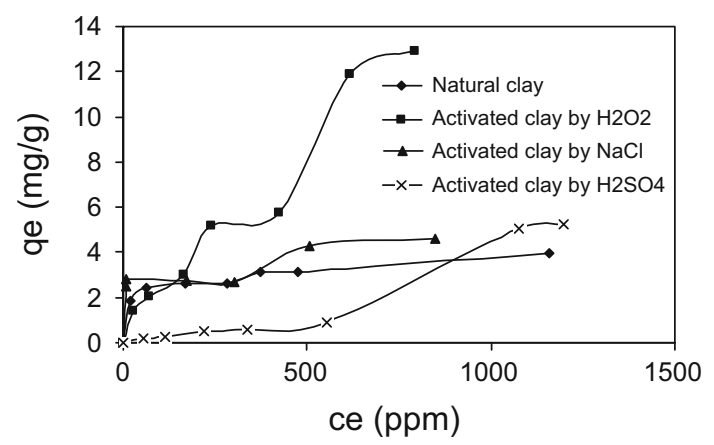

Fig. 5 Activation of Tabbuk clay by different activators for adsorption of cobalt ions

Table 3 Surface area for activated and natural Bahhah clay and Tabbuk clay

\begin{tabular}{lllll}
\hline $\begin{array}{l}\text { Type of } \\
\text { clay }\end{array}$ & $\begin{array}{l}\text { Type of } \\
\text { activators }\end{array}$ & $\begin{array}{l}\mathrm{t} \text {-Plot } \\
\text { external } \\
\text { surface } \\
\text { area } \\
\left(\mathrm{m}^{2} / \mathrm{g}\right)\end{array}$ & $\begin{array}{l}\text { BET } \\
\text { Surface } \\
\text { area } \\
\left(\mathrm{m}^{2} / \mathrm{g}\right)\end{array}$ & $\begin{array}{l}\text { BJH adsorption } \\
\text { cumulative surface } \\
\text { area of pores between } \\
17.000 \text { and } \\
3,000.000 \AA \text { diameter } \\
\left(\mathrm{m}^{2} / \mathrm{g}\right)\end{array}$ \\
\hline $\begin{array}{l}\text { Tabbuk } \\
\text { clay } \\
\text { (natural) }\end{array}$ & Non & 1.0894 & 1.4782 & 1.327 \\
$\begin{array}{c}\text { Tabbuk } \\
\text { clay } \\
\text { activated } \\
\text { by } \mathrm{H}_{2} \mathrm{O}_{2}\end{array}$ & $\mathrm{H}_{2} \mathrm{O}_{2}$ & 1.8800 & 1.4881 & 1.636 \\
$\begin{array}{c}\text { Bahhah } \\
\text { clay } \\
\text { (natural) }\end{array}$ & $\mathrm{Non}$ & 0.4755 & 0.3799 & 0.355 \\
$\begin{array}{c}\text { Bahhah } \\
\text { clay } \\
\text { activated } \\
\text { by NaCl }\end{array}$ & $\mathrm{NaCl}$ & 0.9033 & 0.7809 & 0.822 \\
\hline
\end{tabular}

\section{Results and discussion}

Effect of activators on the adsorption of cobalt ions

\section{Sulfuric acid activator}

Three types of Saudi clay were treated with sulfuric acid. The effect of treatment on clay was examined by determining the adsorption capacities of these clays as shown in Figs. 3, 4, 5. There was no significant enhancement in the adsorption capacity of clays. This might be due to the fact that a part of the clay was disintegrated by acid treatment thus affecting the exchange capacity of clay as an adsorbent for Co ions (Pradas et al. 1994).

\section{Hydrogen peroxide activator}

Three types of Saudi clay were treated with hydrogen peroxide and used as adsorbents for the adsorption of cobalt ions. The equilibrium data are presented in Figs. 3, 4, and 5. After treatment of the Tannuk clay using hydrogen peroxide as activator, the adsorption capacity of Tabbuk clay is improved (Table 3 ). It is also clear from results in Table 3 that the increase in adsorption capacity is due to a relationship between the surface area and the pores diameter and the amount of the adsorption. Because with increasing the pores diameter of the clay, the diffusion of the solute is increased thus resulting in more adsorption. In addition to this, the active site on clay increases due to the increasing surface area of the clay which enhanced the amount of the adsorption.

But in khiber clay, the adsorption capacity did not increase as shown in the isotherm curve. This phenomenon is clear from the fact that the radicals playing significant role in the hydrogen peroxide chemistry are the hydroxyl radical $\left(\mathrm{OH}^{-}\right)$, superoxide radical $\left(\mathrm{O}^{-2}\right)$, and perhydroxyl radical $\left(\mathrm{HO}^{-2}\right)$. These radicals interact with other radicals or ions present on the clay surface (Petri et al. 2011). Therefore, the adsorption capacity did not increase as shown in the isotherm curve which may be attributed to adhesion of radicals of hydrogen peroxide to the clay surface and rendered the cationic ion exchange capacity ineffective for cobalt ions attraction.

\section{Sodium chloride activator}

Three types of Saudi clays were treated with sodium chloride and used as adsorbents for the adsorption of cobalt ions. The equilibrium data is presented in Figs. 3, 4, 5. The adsorption capacity increased especially of Bahhah clay which may be due to increase in the surface area of Bahhah clay by treatment with sodium chloride (Table 3). Activation of Bahhah clay with sodium chloride increased the adsorption capacity due to a relationship between the surface area, pores diameter, and the amount of the adsorption. Any increase in the pores diameter of clay causes increase in the diffusion of solute resulting in more adsorption of ions on clay surface. In addition to this, the active site on clay increases due to the increasing surface area of the clay which enhanced the amount of the adsorption.

However, it was noticed that the adsorption capacity of khiber clay did not increase as shown from the shape of the isotherm curve which may be due to the presence of $\mathrm{Na}^{+}$ ions on the exchange complex of clay showing repulsive effects toward cobalt ions (Banat et al. 2002).

Analysis of the equilibrium isothermal models

Five forms of equilibrium isotherm models namely Langmuir; Freundlich; Langmuir-Freundlich; BET; and Toth isotherm were employed in this study. The equilibrium parameters were estimated by correlating the equilibrium 
Table 4 Langmuir equilibrium parameters for the cobalt adsorption on three types of activated clay by different activators

\begin{tabular}{lllll}
\hline Type of activated clay & Type of activators & $\mathrm{K}(\mathrm{l} / \mathrm{g})$ & $\mathrm{b}(\mathrm{l} / \mathrm{mg})$ & - \\
\hline Khiber clay & & & & \\
& Natural & 0.071 & 0.014 & 0.129 \\
& $\mathrm{H}_{2} \mathrm{O}_{2}$ & 0.0104 & 0.0025 & 0.418 \\
& $\mathrm{NaCl}$ & 0.0176 & 0.0037 & 0.444 \\
& $\mathrm{H}_{2} \mathrm{SO}_{4}$ & 0.0098 & 0.0027 & 0.535 \\
Tabbuk clay & $\mathrm{Natural}$ & 0.151 & 0.046 & 0.114 \\
& $\mathrm{H}_{2} \mathrm{O}_{2}$ & 0.019 & 0.0002 & 0.890 \\
& $\mathrm{NaCl}$ & 1.136 & 0.312 & 0.006 \\
Bahhah clay & $\mathrm{H}_{2} \mathrm{SO}_{4}$ & 0.0058 & 0.0002 & 0.823 \\
& $\mathrm{Natural}$ & 0.0159 & 0.0037 & 0.198 \\
& $\mathrm{H}_{2} \mathrm{O}_{2}$ & 0.0428 & 0.0094 & 0.263 \\
& $\mathrm{NaCl}$ & 0.1071 & 0.0058 & 0.287 \\
& $\mathrm{H}_{2} \mathrm{SO}_{4}$ & 0.0071 & 0.0007 & 0.629 \\
\hline
\end{tabular}

equations with data from equilibrium experiments using non-linear regression technique (i.e., fminsearch function from MATLAB). The estimated equilibrium parameters were utilized to describe the cobalt ions removal by the three types of activated clay used as an adsorbents in a batch and fixed bed columns.

\section{Langmuir isotherm model}

The Langmuir equation assumes that the adsorption of cobalt ions on activated clay is a monolayer mechanism and is applied to evaluate the maximum capacity of the activated clay (Mckay 1996). The Langmuir isotherm equation is written as follows:

$q_{\mathrm{e}}=\frac{K C_{\mathrm{e}}}{1+b C_{\mathrm{e}}}$.

The Langmuir parameters $K$ and $b$ are obtained using the non-linear regression technique with Eq. 2 and given in Table 4.

The dimensionless equilibrium parameter, Ŕ, was obtained to decide the cobalt ions adsorption on the three types of activated clay is favorable or unfavorable using the subsequent form (El-Geundi 2005):

$\dot{R}=\frac{1}{1+b C_{0}}$,

where $b$ is the Langmuir parameter and $C_{0}$ is the initial concentration. The dimensionless parameter values for adsorption of cobalt ions on the three types of activated clay were obtained and presented in Table 4 . The values of the dimensionless parameter were between $0<R<1$. This range showed that the adsorption process is favorable (El-Geundi 2005) and the adsorption of cobalt ions on the three types of activated clay is favorable.
Table 5 Freundlich equilibrium parameters for the cobalt adsorption on three types of activated clay by different activators

\begin{tabular}{llll}
\hline Type of activated clay & Type of activators & $K_{\mathrm{F}}(1 / \mathrm{g})$ & $n(-)$ \\
\hline Khiber clay & Natural & 0.9199 & 4.0766 \\
& $\mathrm{H}_{2} \mathrm{O}_{2}$ & 0.0666 & 1.7782 \\
& $\mathrm{NaCl}$ & 0.1459 & 2.0697 \\
& $\mathrm{H}_{2} \mathrm{SO}_{4}$ & 0.0687 & 1.8633 \\
& $\mathrm{Natural}^{\text {Tabbuk clay }}$ & 1.0550 & 5.5230 \\
& $\mathrm{H}_{2} \mathrm{O}_{2}$ & 0.0351 & 1.1261 \\
& $\mathrm{NaCl}$ & 1.9005 & 8.9273 \\
& $\mathrm{H}_{2} \mathrm{SO}_{4}$ & 0.0140 & 1.1920 \\
& $\mathrm{Natural}$ & 0.3474 & 3.0708 \\
& $\mathrm{H}_{2} \mathrm{O}_{2}$ & 0.3299 & 2.4983 \\
& $\mathrm{NaCl}$ & 0.5017 & 1.8356 \\
& $\mathrm{H}_{2} \mathrm{SO}_{4}$ & 0.0170 & 1.2488 \\
\hline
\end{tabular}

\section{Freundlich isotherm model}

The Freundlich isotherm model describes the experimental data for heterogeneous surface. The Freundlich form is written as follows:

$q_{\mathrm{e}}=K_{\mathrm{F}} C_{\mathrm{e}}^{1 / n}$

The equilibrium constants $K_{\mathrm{F}}$ and $n$ were calculated using non-linear regression technique of Eq. 4 and presented in Table 5. The $n$ values were greater than one which means that the adsorption of cobalt ions on three types of activated clay is favorable (EL-Geundi 1990).

\section{Langmuir-Freundlich isotherm model}

A new model called as Langmuir-Freundlich isotherm model was developed by combining Langmuir and Freundlich. This model has three parameters $K_{\mathrm{c}}, b_{\mathrm{c}}$, and $m$ and is highly suitable for heterogeneous surface (Unuabonah et al. 2007). This form can be written as follows:

$q_{\mathrm{e}}=\frac{K_{\mathrm{c}} C_{\mathrm{e}}^{\frac{1}{m}}}{1+b_{\mathrm{c}} C_{\mathrm{e}}^{\frac{1}{m}}}$

At $m=1$ the model converts to Langmuir. The Langmuir-Freundlich parameters $K_{\mathrm{c}}, b_{\mathrm{c}}$, and $m$ are obtained by using the non-linear regression technique with Eq. 5 and presented in Table 6.

\section{Toth isotherm model}

The fourth model used was Toth model. The Toth model can be written as follows (Unuabonah et al. 2007):

$q_{\mathrm{e}}=\frac{K_{t} C_{\mathrm{e}}}{\left[1+\left(b_{t} C_{\mathrm{e}}\right)^{t}\right]^{\frac{1}{t}}}$. 
Table 6 Langmuir-Freundlich equilibrium parameters for the cobalt adsorption on three types of activated clay by different activators

\begin{tabular}{lllll}
\hline $\begin{array}{l}\text { Type of } \\
\text { activated clay }\end{array}$ & $\begin{array}{l}\text { Type of } \\
\text { activators }\end{array}$ & $K_{\mathrm{c}}(1 / \mathrm{g})$ & $b_{\mathrm{c}}(\mathrm{l} / \mathrm{mg})$ & $\mathrm{m}$ \\
\hline Khiber clay & Natural & 0.1278 & 0.0234 & 1.1867 \\
& $\mathrm{H}_{2} \mathrm{O}_{2}$ & 0.0431 & 0.0088 & 1.3549 \\
& $\mathrm{NaCl}$ & 0.0693 & 0.0126 & 1.3608 \\
& $\mathrm{H}_{2} \mathrm{SO}_{4}$ & 0.0260 & 0.0053 & 1.2807 \\
Tabbuk clay & $\mathrm{Natural}$ & 1.0558 & 0.0026 & 5.4867 \\
& $\mathrm{H}_{2} \mathrm{O}_{2}$ & 0.0946 & 0.0024 & 1.2877 \\
& $\mathrm{NaCl}^{3}$ & 1.9051 & 0.0024 & 8.8986 \\
& $\mathrm{H}_{2} \mathrm{SO}_{4}$ & 0.163 & 0.0159 & 1.88 \\
& $\mathrm{Natural}$ & 0.2885 & 0.0211 & 2.5544 \\
& $\mathrm{H}_{2} \mathrm{O}_{2}$ & 0.3244 & 0.0146 & 2.3208 \\
& $\mathrm{NaCl}$ & 0.1664 & 0.0090 & 1.0967 \\
& $\mathrm{H}_{2} \mathrm{SO}_{4}$ & 0.0936 & 0.0071 & 1.7414 \\
\hline
\end{tabular}

Table 7 Toth equilibrium parameters for the cobalt adsorption on three types of activated clay by different activators

\begin{tabular}{llccl}
\hline $\begin{array}{l}\text { Type of activated } \\
\text { clay }\end{array}$ & $\begin{array}{l}\text { Type of } \\
\text { activators }\end{array}$ & $K_{t}(1 / \mathrm{g})$ & $b_{t}(\mathrm{l} / \mathrm{mg})$ & $T$ \\
\hline Khiber clay & Natural & 0.1418 & 0.0252 & 0.6627 \\
& $\mathrm{H}_{2} \mathrm{O}_{2}$ & 6.1915 & 0.0004 & 0.0863 \\
& $\mathrm{NaCl}$ & 1.2439 & 0.0086 & 0.1514 \\
& $\mathrm{H}_{2} \mathrm{SO}_{4}$ & 0.0225 & 0.0026 & 0.4338 \\
Tabbuk clay & $\mathrm{Natural}$ & 17.6593 & 2.8195 & 0.2428 \\
& $\mathrm{H}_{2} \mathrm{O}_{2}$ & 0.1495 & 0.0004 & 0.2448 \\
& $\mathrm{NaCl}$ & 7.0451 & 1.2220 & 0.0002 \\
& $\mathrm{H}_{2} \mathrm{SO}_{4}$ & 0.299 & 0.0126 & 0.245 \\
Bahhah clay & $\mathrm{Natural}$ & 30.5042 & 1.3985 & 0.1511 \\
& $\mathrm{H}_{2} \mathrm{O}_{2}$ & 6.8693 & 0.0902 & 0.1508 \\
& $\mathrm{NaCl}$ & 2.5863 & 0.0037 & 0.1658 \\
& $\mathrm{H}_{2} \mathrm{SO}_{4}$ & 0.3739 & 0.0005 & 0.1428 \\
\hline
\end{tabular}

The Toth parameters $K_{t}, b_{t}$, and $t$ were obtained using the non-linear regression technique of Eq. 6 and presented in Table 7

\section{BET isotherm model}

This model describes the multilayers of solute adsorbed on the surface of the adsorbent (Sciban et al. 2007). The model can be written as follows:

$q_{\mathrm{e}}=\frac{K_{\mathrm{B}} C_{\mathrm{e}}}{\left(C_{0}-C_{\mathrm{e}}\right)\left[1+\left(b_{\mathrm{B}}-1\right)\left(\frac{C_{\mathrm{e}}}{C_{0}}\right)\right]}$

The BET parameters $K_{\mathrm{B}}$ and $b_{\mathrm{B}}$ are obtained using the non-linear regression technique given in Eq. 8 and presented in Table $\underline{8}$.
Table 8 BET equilibrium parameters for the cobalt adsorption on three types of activated clay by different activators

\begin{tabular}{llrr}
\hline Type of activated clay & Type of activators & $K_{\mathrm{B}}(1 / \mathrm{g})$ & $b_{\mathrm{B}}(1 / \mathrm{mg})$ \\
\hline Khiber clay & $\mathrm{Natural}$ & 0.0005 & -1.3766 \\
& $\mathrm{H}_{2} \mathrm{O}_{2}$ & 0.0004 & -0.6132 \\
& $\mathrm{NaCl}$ & 0.0008 & -0.6631 \\
& $\mathrm{H}_{2} \mathrm{SO}_{4}$ & 0.0003 & -0.7040 \\
Tabbuk clay & $\mathrm{Natural}$ & 0.0016 & -1.4438 \\
& $\mathrm{H}_{2} \mathrm{O}_{2}$ & -0.0029 & 0.2218 \\
& $\mathrm{NaCl}$ & 0.0010 & -0.6700 \\
& $\mathrm{H}_{2} \mathrm{SO}_{4}$ & 0.0001 & -0.1129 \\
Bahhah clay & $\mathrm{Natural}$ & 0.0004 & -1.2562 \\
& $\mathrm{H}_{2} \mathrm{O}_{2}$ & 0.0039 & -0.6544 \\
& $\mathrm{NaCl}$ & 0.5476 & -2.0141 \\
& $\mathrm{H}_{2} \mathrm{SO}_{4}$ & 0 & 1.8108 \\
\hline
\end{tabular}

Estimation the goodness of the fit

The adjusted coefficient of determination, $R_{\mathrm{adj} .}^{2}$, normally is used to evaluate the goodness of the fit (Altin et al. 1998). In addition, Chi-square method $\left(x^{2}\right)$ was applied to evaluate the agreements between the data from the model and the data from equilibrium experiments. The Chi-square $\left(x^{2}\right)$ equation is written as follows:

$x^{2}=\sum_{i=1}^{N} \frac{\left(q_{i_{\text {exp }}}-q_{i_{\text {calc }}}\right)^{2}}{q_{i_{\text {calc }}}}$

where $N$ is the number of data points, $q_{i_{\text {exp }}}$ the experimental amount of cobalt ions adsorption on the clay and $q_{i_{\text {calc }}}$ the calculated amount of cobalt ions adsorption on the clay for a given data point $i$.

The $\left(R_{\text {adj. }}^{2}\right)$ with $\left(x^{2}\right)$ were calculated to assess the goodness of the fit between the equilibrium models and the experimental data. The $\left(R_{\mathrm{adj}}^{2}\right)$ and $\left(x^{2}\right)$ values are given in Table 9 for all the activated clays.

The $\left(R_{\mathrm{adj}}^{2}\right)$ along with the $\left(x^{2}\right)$ show the best model to fit the experimental data through the values of $\left(R_{\mathrm{adj} .}^{2}\right)$ and $\left(x^{2}\right)$. The $\left(R_{\text {adj. }}^{2}\right)$ values varies from 0 to 1 , at $\left(R_{\text {adj. }}^{2}\right)$ value is equal to one, the variation percentage of the amount of cobalt ions adsorbed on the activated clay is hundred percent via the regression technique. In the case of Chi-square method $\left(x^{2}\right)$, the $x^{2}$ has a small value, the result from the model is close to the result of the equilibrium experiment and vice versa.

Considerable variations between these models were confirmed from the values of the $\left(R_{\mathrm{adj}}^{2}\right)$ and $\left(x^{2}\right)$. It was 
Table 9 Comparison of $\left(R^{2}\right)$ and $\left(x^{2}\right)$ for Langmuir, Freundlich, Langmuir-Freundlich, Toth and BET models

\begin{tabular}{|c|c|c|c|c|c|c|c|c|c|c|c|}
\hline \multirow[t]{2}{*}{ Type of clay } & \multirow[t]{2}{*}{ Type of activators } & \multicolumn{2}{|c|}{ Langmuir } & \multicolumn{2}{|c|}{ Freundlich } & \multicolumn{2}{|c|}{ Langmuir-Freundlich } & \multicolumn{2}{|l|}{ Toth } & \multicolumn{2}{|l|}{ BET } \\
\hline & & $x^{2}$ & $R^{2}$ & $x^{2}$ & $R^{2}$ & $x^{2}$ & $R^{2}$ & $x^{2}$ & $R^{2}$ & $x^{2}$ & $R^{2}$ \\
\hline \multirow[t]{4}{*}{ Khiber clay } & Natural & 0.671 & 0.844 & 1.024 & 0.716 & 0.721 & 0.828 & 0.745 & 0.819 & 516,000 & -5.010 \\
\hline & $\mathrm{H}_{2} \mathrm{O}_{2}$ & 0.456 & 0.917 & 0.752 & 0.842 & 0.765 & 0.862 & 0.738 & 0.849 & 23,943 & -0.243 \\
\hline & $\mathrm{NaCl}$ & 0.523 & 0.907 & 0.962 & 0.813 & 0.844 & 0.855 & 0.9 & 0.83 & 29,490 & -0.984 \\
\hline & $\mathrm{H}_{2} \mathrm{SO}_{4}$ & 1.529 & 0.752 & 1.973 & 0.651 & 1.74 & 0.709 & 1.774 & 0.699 & 35,240 & -0.359 \\
\hline \multirow[t]{4}{*}{ Tabbuk clay } & Natural & 0.270 & 0.690 & 0.0602 & 0.937 & 0.060 & 0.937 & 0.102 & 0.890 & 192,810 & -11.58 \\
\hline & $\mathrm{H}_{2} \mathrm{O}_{2}$ & 2.364 & 0.947 & 1.578 & 0.950 & 1.730 & 0.901 & 1.803 & 0.899 & $-42,160$ & 0.424 \\
\hline & $\mathrm{NaCl}$ & 0.857 & 0.286 & 0.586 & 0.526 & 0.586 & 0.525 & 0.673 & 0.448 & $1,395,000$ & -5.754 \\
\hline & $\mathrm{H}_{2} \mathrm{SO}_{4}$ & 1.497 & 0.969 & 0.9150 & 0.973 & 0.84 & 0.916 & 0.871 & 0.909 & 271,300 & 0.388 \\
\hline \multirow[t]{4}{*}{ Bahhah clay } & Natural & 0.710 & 0.797 & 0.185 & 0.926 & 0.181 & 0.928 & 0.197 & 0.916 & $1.72,280$ & -3.349 \\
\hline & $\mathrm{H}_{2} \mathrm{O}_{2}$ & 0.111 & 0.961 & 0.386 & 0.869 & 0.380 & 0.878 & 0.327 & 0.889 & 10,600 & -1.749 \\
\hline & $\mathrm{NaCl}$ & 1.710 & 0.924 & 3.177 & 0.857 & 2.159 & 0.909 & 2.921 & 0.871 & 346.67 & 0.3490 \\
\hline & $\mathrm{H}_{2} \mathrm{SO}_{4}$ & 0.156 & 0.993 & 0.199 & 0.989 & 0.912 & 0.891 & 0.638 & 0.940 & $3,030,000$ & -0.463 \\
\hline
\end{tabular}

found that, Langmuir model fits the experimental data well for Khiber activated clay in all cases. In addition, Langmuir model fits the experimental data well for activated Bahhah clay. This might be due to the fact that the cobalt ions adsorbed on the clay as a monolayer. The study findings agree with those of Adebowale et al. (2006); Hammed et al. (2006); Raji and Anirudhan (1997); and Al-Asheh et al. (2002) who concluded that the Langmuir is a valid monolayer sorption on a surface containing a finite number of binding sites. They further stated that the adsorbent is more homogenous in surface structure and formation of monolayer at the outer layer of the absorbent. While Freundlich model and Langmuir-Freundlich model fit the experimental data well for natural Tabbuk clay and activated Tabbuk clay by $\mathrm{NaCl}$. In addition, Freundlich model and LangmuirFreundlich model fit the experimental data well for natural Bahhah clay. Also, it was found that, Freundlich model fits the experimental data well for Tabbuk clay when activated by $\mathrm{H}_{2} \mathrm{O}_{2}$ and $\mathrm{H}_{2} \mathrm{SO}_{4}$. In all the three activated clays, the BET model proved to be the worst model in fitting the experimental data. This may be due to the absence of cobalt multilayer on the activated clays.

\section{Conclusions}

The influence of different types of activator on enhancing the adsorption capacity of these clays demonstrated that the enhancement of adsorption capacity depends on the type of activator and clay. However, the adsorption capacity of Khiber clay did not show any improvement after treatment.

The Langmuir isotherm agreed most favorably with the experimental data for Khiber clay in all the cases and for Bahhah clay activated by $\mathrm{H}_{2} \mathrm{O}_{2}, \mathrm{NaCl}$ and $\mathrm{H}_{2} \mathrm{SO}_{4}$.
Freundlich model and Langmuir-Freundlich model fitted well with the experimental data for natural Tabbuk clay, activated Tabbuk clay by $\mathrm{NaCl}$, and natural Bahhah clay. In the case of activated Tabbuk clay, Freundlich model fitted well with the experimental data of Tabbuk clay activated by $\mathrm{H}_{2} \mathrm{O}_{2}$ and $\mathrm{H}_{2} \mathrm{SO}_{4}$. Finally, the BET model is correlated with the experimental data unsuccessfully for these three activated clays.

Open Access This article is distributed under the terms of the Creative Commons Attribution License which permits any use, distribution, and reproduction in any medium, provided the original author(s) and the source are credited.

\section{References}

Adebowale KO, Unuabonah IE, Oluowolabi BI (2005) Adsorption of some heavy metal ions on sulfate- and phosphate- modified kaolin. Appl Clay Sci 29(2):145-148

Adebowale KO, Unuabonah IE, Oluowolabi BI (2006) The effect of some operating variables on the adsorption of lead and cadmium ions on Kaolite clay. J Hazard Mat B134:130-139

Al-Asheh S, Banat F, Al-Rousan D (2002) Adsorption of copper, zinc and nickel from single and binary metal ion mixture on to chicken feathers. Adsorpt Sci Technol 20(9):849-864

Al-Asheh S, Banat F, Abu-Aithha L (2003) The removal of methylene blue from aqueous solutions using activated and non-activated bentonites. Adsorpt Sci Technol 21(5):451-462

Altin O, Ozbelge HO, Dogu T (1998) Use of general purpose adsorption isotherms for heavy metal-clay mineral interactions. J Colloid Interface Sci 198:130-140

Banat F, Al-asheh S, Abu-aitah L (2002) Examination of the effectiveness of physical and chemical activation of natural bentonite for the removal of heavy metal ions from aqueous solutions.

Brezonik PL (1974) Analysis and speciation of trace metals in water supply, in aqueous environmental chemistry of metals. In: Rubin AJ (ed) Aqueous-environmental chemistry of metals. Ann Arbor Science Publishers, Ann Arbor, pp 167-191 
Diaz M, Cambier P, Brrndle J, Prost R (2007) Functionalized clay heterostructures for reducing cadmium and lead uptake by plants in contaminated soils. Appl Clay Sci 37:12-22

Dogan M, Turhan Y, Alkan M, Namli H, Turan P, Demirbas O (2008) Functionalized sepiolite for heavy metal ions adsorption. Desal 230(1-3):248-268

El-Geundi MS (2005) Adsorption equilibrium of a Herbicide (Pendimethalin) onto natural clay. Adsorpt Sci Technol 23:437

EL-Geundi MS (1990) Adsorption equilibria of basic dyestuffs onto maize cob. Adsorpt Sci Technol 7:114

Emsley J (1992) The elements, 2nd edn. Clarendon Press, Oxford 54

Eren E (2008) Removal of copper ions by modified unye clay, Turkey. J Hazard Mat 159(2-3):235-244

Hammed BH, Din AM, Ahmed AL (2006) Adsorption of methylene blue onto bamboo based activated carbon kinetics and equilibrium studies. J Hazard Mat 137(3):695-699

Mckay G (1996) Use of adsorbents for the removal of pollutants from waste water. CRC Press Inc., Boca Raton

Patterson J, Passino R (1987) Metal speciation, separation and recovery. Lewis Publishers Inc., Chelsea

Petri BG, Watts RJ, Teel AL, Huling SG, Brown RA (2011) Fundamentals of Isco using hydrogen peroxide. In: R. L. Siegrist et al. (eds.), In situ chemical oxidation for groundwater remediation, doi:10.1007/978-1-4419-7826-4_2, \# Springer Science+Business Media, LLC 2011 pp 33-88

Pradas EG, Villafranca M, Viciana MS, Campo AG (1994) Adsorption of chlorophyll-a from acetone solution on natural and activated bentonite. J Chem Technol Biotechnol 61:175-178

Raji C, Anirudhan TS (1997) Chromium (VI) adsorption by sawdust carbon: kinetics and equilibrium. Indian J Chem Technol 4:228-236

Sciban M, Radetic B, Kevresan Z, Klasnja M (2007) Adsorption of heavy metals from electroplating wastewater by wood sawdust. Bioresour Technol 98(2):402-409

Singh SP, Ma LQ, Harris WG (2001) Heavy metal interaction with phosphatic clay: sorption and desorption behavior. J Environ Qual 30(6): 1961-1968

Stathi P, Litina K, Gournis D, Giannopoulos T, Deligiannakis Y (2007) Physicochemical study of noval organo clays as heavy metal ion adsorbents for environmental remediation. J Colloid Interface Sci 316:298-309

Suraj G, Iyer SP, Lalithambika M (1998) Adsorption of cadmium and copper by modified kaolinites. Appl Clay Sci 13(4):293-306

Unuabonah E, Olu-Owolabi B, Adebowale K, Ofomaja A (2007) Adsorption of lead and cadmium ions from aqueous solutions by tripolyphosphate-impregnated kaolinite clay. Colloid Surf 292:202-211 